\title{
G. Charlot：電気化学的方法による非水溶媒中の反応の解析
}

パリ科学アカデミー会貣, パリ大学理学部教授 G・シ ヤルロー博士は4月3日京都に打ける国際分析化学会議 (ICAC) において慓記のような題目について特別請演を された。

シャルロー教授はパリ市立工業大学École Supérieure de Physique et de Chimie Industrielle de la Ville de Paris 学卒業後，母校において分析化学の研究および教 育に当たられ，現在ではパリ大学理学部および核科学技 術研究所 Institut National des Sciences et Techniques Nucléaires の分析化学の教授を兼衩ておられ，その間独 特のすぐれた教育的・学閣的成果をいくつかの著笪や諭 交に発表されたが，旮れらについては広く知られている とおりである・また常に分析化学の重要性定強調されて， かつてはパリ市立工業大学とパリ大学薬学部にしかなか った分析化学の講座を, パリ大学理学部はじめ, いくつ かの大学において設立与る原動力となったととは特筆す ベきである.

シャルロー教授注 Analysis (分析, 解析) の専門家で あるが，同時に Synthesis(合成，まとめ) にもすぐれて おられる. 先生の化学的な，また洔には哲学的とさえ思 われる深い思素は多くの著作や諭文のなかに合成してま とめられている. その符 1 注 Brønsted の理腧の一般化 によって，溶液内の反忘をプロトン，電子，イオン，お よび極性分子といった各種粒子の交換反応と考えて，全 体としては握することであった＼cjkstart第 2 には電気化学的 反応点電流一電圧曲線の解析によって理解すること，第 3 には溶融塭を含めた非水溶媒中の化学反応の解析であ る. 今回の講演の内容は第 2 , 第 3 の研究にまたがるも のと考えられる。

\section{灌 演 概 要}

分析化学の一般的な目的のなかで, 最も重要なことは, 溶液内の反応の解析である．そしてこれは化学的あるい は電気化学的な分析法荙つくるときと同じような考え方 で行なわれる. 分析化学者が，純学問的な研究において も, 工業的な研究においても，このような役割壳果たさ なければならないことがあまり認められていないこと は残念なことである.したがって分析化学の教育に携わ るものは，このように化学分析*と現象の解析*という， 分析化学のもっている二つの重要な役割を志れてはなら

\footnotetext{
*分析も解析も Analyse という語である。
}

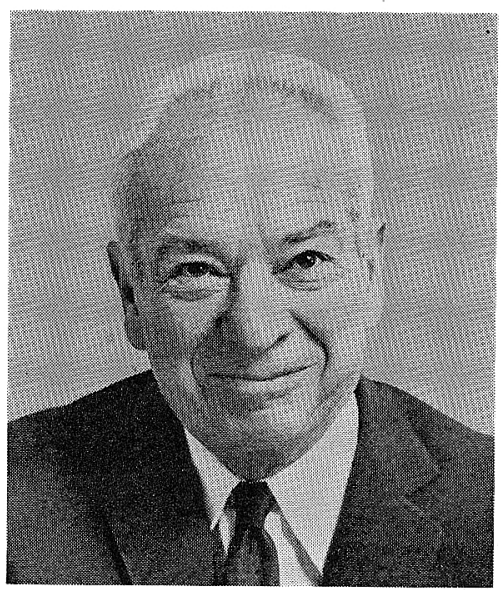

Charlot 教授

ない.

今，最も多くの可能性岁をっている分野は非水溶媒系 であると思われる：そしてこの分野で研究している分析 化学者の数が多いのも偶然のことでは宗い，この分野で 最も有効な研究方法は, いろいるな種類の電気化学的方 法である. 今日で注占典的といえる電流-電圧曲線の解 析によって，与えられた電極に対する各化学種のふるま い学予知することができる。定電里クーロメトリーによ って反応にあずかる電子数を決定することもできるし， 電解生成物を分析に供することもできる.

電気化学分析を行なう場合に，溶媒や需極を選び, $\mathrm{pH}$ を変え，錯形成を考虙したりなどすることによって，い ろいろの可能性が生まれてくることになる. 逆に電気化 学的反応を利用する第 2 の分野は, 化学反忘の解析であ る.一つの電極に㧍ける電流一電圧曲線の解析によって 反応を追跡することができる，この解析によって有用は 知見が得られるが，二つのふつごうなことがあることに 注意しなけれ壮ならない，その一つは無関係塩定加壳て 溶液に電導性觉与光てお就ばならないこと，もら一つ はおそい酸化還元采の場合に，用いる電極によって得ら れる知見が異なり，溶媒自身の酸化あるい:還元が問題 になる場合が多いことである。

ここでは一般的にいらいろの方法について述べること はできないので，わたしのところでやった一つの例を述 ベることにする. それは硫酸一水の混合溶媒の性質に関 するもので，その極端な場合は無水硫酸ということにな 
る. 天然ガス精製の副産物として膨大な量のイオウが生 産されており，国によっては硫酸は最も安価な溶媒の一 つになっている，ところがこの溶媒については経験的な 知識しかなく, 反応を予知するための一般的性質はあま りよく知られていない.

市販の $18 M$ 濃硫酸は, 硫酸のモル分率で 0.8 となり, $15 M$ 濃硫酸は, 硫酸モル分率 0.5 である.したがって硫 酸が水と次のように反応することを考えると，このよう な濃硫酸はきわめて少量の水しか含安ないことになる.

$$
\mathrm{H}_{2} \mathrm{SO}_{4}+\mathrm{H}_{2} \mathrm{O} \longrightarrow \mathrm{HSO}_{4}^{-}+\mathrm{H}_{3} \mathrm{O}^{+}
$$

すなわち，濃硫酸はほとえど水を含まない非水溶媒で あり，12M 硫酸でも, 硫酸のモル分率は 0.3 であって, 非水溶媒と考えてよい.

このように非水溶媒と考えられる $12 M$ 以上の硫酸一水 混合溶媒は, 各種の物質の溶解度, 酸化還元, 錯形成反 応などに関してすばらしい性質を有している．また多く の有機溶媒と混ざり合うことも特筆すべきことである. さらにこれら溶媒は誘電率およそ100の非常に解離性の 溶媒で, 電解質をわざわざ加えて実験する必要がない.

このような溶媒の一般的性質をは握するために, 溶媒 の各種性質, 特に酸化還元電位と塩基性の尺度を共通の 基礎の上に確立しなければならない. この場合水の性質 と比較するのがいちばんよい。一つの化学種が二つの溶 媒間に平衡にあるとき, その活量は両溶媒において等し いと考える.

酸化還元電位については困難はないようである・たと えば，フェロセンーフェリシニウム対のような酸化還元 系は第一次近似として溶媒に無関係に電位が決まること が知られている.すなわちこのような大きいイオンは溶 媒和の影響を受けないので，水中で $+0.40 \mathrm{~V}$ の標準電 位を示すこの系は, 水一硫酸系でも $E_{0}=0.40 \mathrm{~V}$ であると 考えてよい. このようにとると水中の水素電極の標準電 位を基準にとったことになる.

以上のことが正しいことを確かめるために, 24 種の炭 化水素を調ベ，そのうちからペリレン，テトラセンおよ びトリフェニルカルボニウムの 3 化合物が可逆性, 溶解 度, 電位の範囲の点で好つごうであることがわかった。

ペリレンは硫酸によって酸化されて陽イオンラジカル $\mathrm{Pn}^{+}$になり, $\mathrm{Pn}^{+} / \mathrm{Pn}^{2+}$ は水中の標準水素電極に対し て, $1.45 \mathrm{~V}$ の標準電位を示す. テトラセンも $\mathrm{Tc}^{+} / \mathrm{Tc}^{2+}$ の電位は $E_{0}=1.45 \mathrm{~V}$ であり, トリフェニルカルボニウ ム $\phi_{3} \mathrm{G}^{+}$は $\phi_{3} \mathrm{C}^{2+}$ に酸化され, $E_{0}=2.45 \mathrm{~V}$ である.

参照電極として, 水銀-硫酸第一水銀-飽和硫酸カリウ ム水溶液を朋いて，この電極をフェロセンーフェリシニ
ウム系で $15 M$ 硫酸まで愉定することができた。 $15 M$ 以 上の濃度になるとフェロセン自身が溶媒によってゆっく り酸化されるので，この系を用いることができない，し かし $\mathrm{Pn}^{+} / \mathrm{Pn}^{2+}$ および $\mathrm{Tc}^{+} / \mathrm{Tc}^{2+}$ 系炎用いると, $12 M$ から $15 M$ ，さらに $15 M$ から $18 M$ 硫酸までの検定をす ることができた。安た $\phi_{3} \mathrm{C}^{+} / \phi_{3} \mathrm{C}^{2+}$ 系も用いることが できた. このようにしてフェロセンーフェリシニウム系 の電位が溶媒に無関係に決められるという，われわれの 仮定を確かめることができたわけである.

酸化還元電位の測定によって，この硫酸溶媒中では水 よりも強い酸化をすることができることがわかる， pH $=0$ の水中では $1.23 \mathrm{~V}$ が酸化の限界であるが，硫酸溶 媒では $3 \mathrm{~V}$ まで可能である。また $\mathrm{Ti}(\mathrm{IV}) / \mathrm{Ti}(\mathrm{III})$ 系は 硫酸 $7 M$ 以上で速い系である.

この溶媒系では

1. 水を多く含毛 硫酸 $<12 M$ の采

2. 無水の系 (硫酸 $>12 M$ )

を区別して考えるほらがよい，水の多い系では溶媒の遠 元とは $\mathrm{H}^{+}$の還元であり, $12 M$ 以上では溶媒の還元と は硫酸の還元である。なた $13 M$ までは溶媒の酸化は水 の酸化であるが，13M 以上では硫酸の酸化である.

水と性質がずっと変わるのは無水の系であって，12M 以上ではアルカリ土類や鉛の硫酸塩は可溶性であり, 2 価や 3 価の金属の硫酸塩が難溶性となる．また $12 M$ 以 上の硫酸は多くの有機溶媒と混ざり，このような性質は 無機化学や有機化学において数多くの応用を見いだすも のと思われる。

水中の $\mathrm{pH}$ の尺度をこの溶媒系に拡張するために，た とえばハメットの酸度関数のようなものが提案されてい る.このような尺度は溶媒に無関係ではない，そこで適 当な $\mathrm{pH}$ 指示薬，あるいはプロトンの関与する適当な酸 化還元系があれば，このような溶媒系の酸性の尺度を決 めることができる. $12 M$ 以下の系では水素電極を用い ることができるが， $12 M$ 以上では硫酸が還元されて氷 素電極は正常に働かない.

ずっと以前に在仏中, 物静かに講演されるシャルロー 教授を見てきた筆者にとって，今回の講演はたいへんな 熱演であったと思われた：途中から原稿をやや離れて話 されたこともあって，同時通訳がとぎれがちになったこ とはまことに残念であった。

本稿執筆にあたり，各種資料を提供していただいた藤 永太一郎教授をはじめ, 宗森信教授, 佐藤正憲先生に 厚くお礼申し上げます。

（名古屋大学理学部 田中元治） 